\title{
Pengaruh Pujian Penyembahan Dan Musik Iringan Terhadap Minat Kehadiran Ibadah Remaja Di Gbi My Home Tanjung Pinang
}

\author{
Nobel Siagian ${ }^{1 *}$, Fredy Simanjuntak ${ }^{2}$, Johannes Tarigan ${ }^{3}$, Mega Riana ${ }^{4}$ \\ 1,2,3,4Prodi Teologi, STT Real Batam \\ nobelsiagian03@gmail.com
}

\begin{abstract}
The purpose of this study is to reveal and analyze the influence of worship accompaniment music on the interest in the presence of youth. Youth Transformation has a great influence on young people today. The method used in this research is survey research with a quantitative research approach. The population in this study were all teenagers who worshiped at Youth Transformation GBI My Home Tanjungpinang aged 15-18 years as many as 50 people. The results showed that worship and accompaniment had a positive and significant effect on interest in attending worship. Description Praise Worship and Accompaniment Music shows good results. Likewise, the description of Youth Worship Attendance aged 15-18 years at GBI My Home Tanjung Pinang showed good results, and the correlation value of Praise Worship and Accompaniment Music on Youth Worship Attendance was in a strong position.
\end{abstract}

Keywords: Praise, Worship, Music, Interest, Teenager.

\begin{abstract}
Abstrak
Tujuan penelitian ini adalah mengungkapkan dan menganalisis pengaruh musik iringan ibadah terhadap minat kehadiran remaja Youth Transformation besar pengaruhnya bagi kawula muda dijaman sekarang ini. Metode yang digunakan dalam penelitian ini yaitu penelitian survei dengan pendekatan penelitian kuantitatif. Adapun yang menjadi populasi pada penelitian ini yaitu seluruh remaja yang beribadah di YouthTransformation GBI My Home Tanjungpinang yang berusia 15-18 Tahun sebanyak 50 orang. Hasil penelitian menunjukkan bahwa Pujian Penyembahan dan musik iringan berpengaruh positif dan signifikan terhadap minat kehadiran untuk beribadah. Deskripsi Pujian Penyembahan Dan Musik Iringan menunjukkan hasil yang baik. Begitu pun dengan deskripsi Kehadiran Ibadah Remaja Usia 15-18 Tahun Di Gbi My Home Tanjung Pinang menunjukkan hasil yang baik, serta nilai korelasi Pujian Penyembahan Dan Musik Iringan terhadap Kehadiran Ibadah Remaja berada pada posisi kuat. Kata kunci: Pujian, Penyembahan, Musik, Minat, Remaja.
\end{abstract}




\section{PENDAHULUAN}

Musik memiliki keunikan tersendiri dalam ibadah sebagaimana yang dikatakan Luther musik adalah penguasa dan pengatur emosi manusia. Musik dapat dipakai untuk menghibur, menenangkan, bahkan dapat mempegaruhi suasana hati sedih ataupun senang. Musik merupakan salah satu alat yang paling efektif untuk menguasai emosi manusia. Dalam Ibadah kontemporer tampaknya musik memiliki daya tarik tersendiri bagi para remaja seperti yang terjadi di GBI My Home Tanjungpinang. Namun bagian terpenting dalam Pujian penyembahan dan musik iringan bukan hanya mengakomodasi emosi diri namun juga emosi ilahi.

Di zaman kontemporer Manusia tampaknya memiliki musikalitas bawaan dalam ibadah dapat menghibur saat dalam kesedihan, musik dapat memotivasi semangat dalam masa perjuangan, musik dapat menjadi sarana ungkapan cinta kepada seseorang dan musik juga dapat merenggangkan pikiran saat menghadapi kepenatan hidup. Musik menjadi salah satu mata rantai liturgi artinya menjadi bagian yang tak terpisahkan dari keseluruhan rangkaian ibadah. Ibadah akan terganggu apabila musik berjalan tidak sebagaimana mestinya.

Di jaman millennial ini Ibadah yang berlangsung dengan musik iringan akan merubah suasana ibadah akan terasa berbeda terutama bagi remaja yang menjadikan musik iringan suatu kesukaan. Musik tidak terlepas dari kehidupan remaja dan begitu relevan bagi remaja. Banyak remaja yang hadir dalam ibadah cenderung dipengaruhi oleh iringan musik kontemporer yang ringan seperti yang pada umumnya tren di dalam ibadah gereja beraliran pentakosta-kharismatik. Kaum milenial memiliki kecenderungan yang kuat dalam kesukaan music. Banyaknya anak-anak muda hanya mengikuti tren tetapi tidak tahu esensi atau pengertian musik itu sendiri, sehingga tidak banyak remaja tidak sadar bahwa musik sedang membawa seseorang kepada pestapora, kepada kekerasan, kepada pemujaan setan yaitu dengan cara meminum darah ayam dan melakukan hal-hal yang tidak bermoral. Oleh sebab itu penulis melakukan penelitian mengenai pengaruh musik iringan ibadah terhadap minat kehadiran remaja Youth Transformation besar pengaruhnya bagi kaula muda dijaman sekarang ini.

Dalam kitab Perjanjian Lama seorang pemuji penyembah, pembuat alat musik, pemain alat musik yang menjadi gaya hidup seorang daud dan yang sampai hari ini banyak gereja bahkan manusia belajar tentang raja Daud oleh karna itu musik menjadi sesuatu yang tidak asing lagi bagi manusia. Sebagaimana kita tahu musik terus berkembang dan diterima oleh semua kalangan, baik muda, tua, lansia bahkan anak-anak. Seiring berjalannya 
waktu musik berubah menjadi kebutuhan dan perlahan menjadi bagian dari kehidupan manusia.

Menurut Penulis Musik dapat menghibur saat dalam kesedihan, musik dapat memotivasi semangat dalam masa perjuangan, musik dapat menjadi sarana ungkapan cinta kepada sang kekasih dan musik juga dapat merenggangkan pikiran saat menghadapi kepenatan hidup.

Berdasarkan pengamatan penulis bahwa seluruh ciptaan Tuhan mengandung bunyi - bunyian atau musik. Tujuan dan maksud Allah menciptakan segala sesuatu bukan hanya secara kebetulan, melainkan Ia ingin menerima pujian-pujian dari ciptaan-Nya, melihat dari tradisi bahwa Yubal anak Lamekh, yang menjadi bapak semua orang yang memainkan kecapi dan seruling Kejadian 4:21. Tentu saja pada mulanya penggunaan musik itu terbatas pada kehidupan ibadah kepada Allah pada masa itu.

Menurut Martasudjita dalam buku berjudul Panduan Memilih Nyanyian Liturgi bahwa "musik itu mampu mempengaruhi seseorang yang mengalami kesedihan sehingga meneteskan air mata saat mendengarkan alunan musik yang begitu menyentuh hati dan jiwa. Inilah yang dimaksud musik mempunyai kemampuan mendamaikan hati yang gundah". ${ }^{1}$ Musik begitu penting bagi setiap manusia sebab bukan hanya membuat seseorang menjadi sedih atau senang tetapi musik menjadi sarana dimana kuasa Tuhan bekerja, sebagaimana kitab 1 samuel 16:23 "Dan setiap kali apabila roh yang dari pada Allah itu hinggap pada Saul, maka Daud mengambil kecapi dan memainkannya; Saul merasa lega dan nyaman, dan roh yang jahat itu undur dari padanya", dan didalam kitab 2 raja-raja 3:15 Elisa hendak meminta pewahyuan dari pada Tuhan maka Elisa diliputi Roh Tuhan lewat pemetik kecapi yaitu musik. Itulah sebabnya penulis menulis musik menjadi salah satu bagian penting dalam sebuah ibadah liturgi.

Musik menjadi salah satu mata rantai liturgi artinya menjadi bagian yang tak terpisahkan dari keseluruhan rangkaian ibadah. Ibadah akan terganggu apabila musik berjalan tidak sebagaimana mestinya. Musik memberi bobot dan mempertajam pengungkapan makna iman dan perasaan yang tidak cukup jika diungkapkan dengan kata-kata sehingga kegiatan ibadah tidak jatuh pada ruang akal-perasaan semata, tetapi memasuki kedalaman (depth) spiritual. ${ }^{2}$

${ }^{1}$ Emanuel Martasudjita and Joseph Kristanto, Musik Dan Nyanyian Liturgi : Panduan Untuk Memahami Dan Memilih Dan Nyanyian Liturgi (Yogyakarta: Kanisius, 2007). Hal. 10

${ }^{2}$ Christina Mandang, Serba - Serbi Mengiringi Nyanyian Jemaat (Surabaya: GKI Pondok Tjandra Indah, 1998). Hal. 2 
Musik Iringan dalam ibadah bukan hanya menyatu dengan bagianbagian lain liturgi, melainkan juga dengan hati/batin jemaat yang beribadah. Pada hakekatnya musik dalam ibadah berfungsi melayani. Pengiring musik bukan tontonan, demikian juga jemaat bukan penonton. Pengiring musik adalah perantara yang rindu berjumpa dengan Tuhan. Menurut Abraham Soei Ndoen dalam buku Revolusi Penyembahan Profetik bahwa "penyembahan adalah semua ungkapan hati kita yang mengasihi, menghormati, dan mengagungkan Tuhan, dalam semua bentuk kehidupan kita yang memuliakan Tuhan yang fokus penyembahan kita yaitu kepada bapa sorgawi". 3

Di jaman millennial ini Ibadah yang berlangsung dengan musik iringan akan merubah suasana ibadah akan terasa berbeda terutama bagi remaja yang menjadikan musik iringan suatu kesukaan. Remaja dalam hal ini adalah orang yang berusia antara 15-18 tahun. "Gereja suku atau penatuapenatua yang melihat pola ibadah remaja jaman sekarang akan menilai ibadah yang mereka ikuti hanya untuk bersenang - senang atau tidak sunguhsungguh". ${ }^{4}$ Padahal bagi Remaja musik iringan dapat membuat jiwa mereka tenang dan dapat mengeskpresikan pujian penyembahan dengan segenap kekuatan mereka seperti raja Daud (2 samuel 4:16). Remaja sangat senang dengan musik yang berenergik, genre atau jenis musik pop dicampur rock menjadi daya tarik bagi remaja. Berbagai aliran musik lain yang digemari remaja gospel, jazz, blues, funk, rock, pop, ska, reggae, hingga hip-hop rap, rapcore dan black metal yang sudah melekat di telinga remaja sekarang. Maka tidak heran juga ada remaja yang sangat suka dengan musik aliran heavy metal ini dimana dari personil bandnya pun adalah pemuja setan.

Banyaknya anak-anak muda hanya mengikuti tren tetapi tidak tahu esensi atau pengertian musik itu sendiri, sehingga tidak banyak remaja tidak sadar bahwa musik sedang membawa seseorang kepada pestapora, kepada kekerasan, kepada pemujaan setan yaitu dengan cara meminum darah ayam dan melakukan hal-hal yang tidak bermoral. Sebab tidak serta-merta semua jenis musik atau genren yang disukai oleh remaja dapat membangun iman, tetapi remaja kristen wajib melihat kehidupan personil musik dan untuk pemujaan terhadap siapa musik atau lirik lagu tersebut dikarang.

Gereja Bethel Indonesia My Home mempunyai komunitas remaja kristen yaitu bernama Youth Transformation, dimana komunitas remaja

\footnotetext{
${ }^{3}$ Bram Soei Ndoen, Revolusi Penyembahan Profetik (Yogyakarta: ANDI, 2007). Hal. 4

${ }^{4}$ Wilfred J Samuel, Kristen Kharismatik (Jakarta: BPK Gunung Mulia, 2007). Hal. 
kristen ini bertempat di J1. Rawasari, kompleks PSMTI no. 1 Tanjungpinang. Berdasarkan latar belakang masalah yang telah diuraikan, penelitian mengenai pengaruh musik iringan ibadah terhadap minat kehadiran remaja Youth Transformation besar pengaruhnya bagi kaula muda dijaman sekarang ini.

\section{METODE}

Metode penelitian yang digunakan adalah metode penelitian survey dengan pendekatan kuantitatif (Quantitative Research) menjadi metode penelitian yang dipilih dalam penelitian ini untuk menjawab pertanyaan-pertanyaan penelitian. Dalam penyusunan instrument atau alat pengumpul data, variabel-variabel yang menjadi acuan utama peneliti dalam menyusun angket, terdiri atas angket tentang pujian penyembahan, music iringan dan minat kehadiran remaja Youth Transformation GBI My Home. Adapun cara-cara yang digunakan dalam analisa data adalah analisis korelasi dan analisis regresi.

\section{HASIL DAN PEMBAHASAN \\ Defenisi dan Asal-Usul Ibadah}

Kata Ibadah dalam Alkitab dapat diartikan sebagai setiap pelayanan yang dilakukan oleh seorang abdi untuk tuannya yang dilakukan dalam ketaatan, kesetiaan dan dengan perasaan hormat. Seluruh kehidupan seorang abdi adalah milik sang tuan sehingga seluruh hidupnya merupakan pelayanan kepada tuannya. Gereja-gereja seringkali menggunakan istilah "liturgi" untuk menerjemahkan ibadah. Namun, istilah liturgi itu sendiri mula-mula justru memiliki arti profanpolitis. "Liturgi adalah istilah yang berasal dari bahasa Yunani, leitourgia, yang berarti kerja bersama. Kerja bersama ini mengandung makna peribadatan kepada Allah dan pelaksanaan kasih, dan pada umumnya istilah liturgi lebih banyak digunakan dalam tradisi Kristen, antara lain umat Katolik." Dalam dunia Yunani Kuno. Liturgi adalah pekerjaan yang dilakukan oleh rakyat; dilakukan demi kepentingan kota atau negara. "Tindakan ini menunjuk kerja bakti atau kerja pelayanan yang tidak dibayar, iuran atau sumbangan dari masyarakat 
yang kaya, dan pajak untuk masyarakat atau negara. Hal ini berarti bahwa liturgi melibatkan pelayanan yang diberikan secara sukarela." 5

Berbicara mengenai bbadah tentunya tidak terlepas dari pujian penyembahan dan musik iringan. Dalam tulisannya Ceria dkk mengartikan penyembahan merupakan hubungan intim yang dilakukan oleh seseorang yang memiliki pemahaman yang benar tentang Firman Tuhan, kemurahan dan sifat Allah itu sendiri. ${ }^{6}$ Musik, pujian, dan penyembahan adalah tiga unsur penting dalam kebaktian.

Ibadah sendiri tidak terlepas dari Pujian penyembahan dan music iringan. Dalam tulisannya Ceria dkk mengartikan pujian penyembahan merupakan hubungan intim yang dilakukan oleh seseorang yang memiliki pemahaman yang benar tentang Firman Tuhan, kemurahan dan sifat Allah itu sendiri.

Ibadah yang diketahui dan dilakukan oleh gereja-gereja masa kini tidak terlepas dari tradisi umat Yahudi. Alkitab (Perjanjian Lama dan Perjanjian Baru) mencatat bahwa tradisi gereja saat ini dalam kaitannya dengan ibadah atau liturgi berakar dari tradisi, budaya dan dogma Yahudi. Tradisi Yudaisme yang mempengaruhi tradisi gereja masa kini terlihat dari penggunaan tata waktu ibadah, tempat ibadah dan perayaan liturgi yang diambil dari pola ibadah Yahudi, seperti gereja mengutamakan peribadahan pada hari pertama atau sejajar dengan hari Minggu, daripada hari ketujuh atau sejajar dengan hari Sabtu. Orang Kristen mula-mula juga menggunakan Bait Allah, Sinagoge dan rumah tangga untuk beribadah. "Begitu juga dengan tata waktu ibadah harian, mingguan, tahunan, dan berbagai perayaan liturgi diadopsi dari pola ibadah Yahudi. Peribadahan yang dilakukan gereja masa kini juga mengikuti cara peribadahan Israel yang bersifat monoteis." $"$ Hal. 13-14

${ }^{5}$ James F White, Pengantar Ibadah Kristen (Jakarta: BPK Gunung Mulia, 2005).

${ }^{6}$ Ceria, Fredy Simanjuntak, and Evans Dusep Dongoran, “Kajian Teologis Ritual Nyangahatn Dalam Perspektif Penyembahan Menurut Alkitab," Real Didache 5, no. 1 (2020): 89-97.

${ }^{7}$ Rasid Rachma, Hari Raya Liturgi: Sejarah Dan Pesan Pastoral Gereja (Jakarta: BPK Gunung Mulia, 2005). Hal. 5-6 


\section{Pujian Penyembahan}

Hasil penelitian menunjukkan bahwa deskripsi Pujian penyembahan dalam ibadah Youth GBI My Home Rawasari yang menjadi daya Tarik bagi remaja dan pemuda. Terbukti dari perolehan rata-rata skor sebesar 4.28 yang menunjukkan kategori baik.

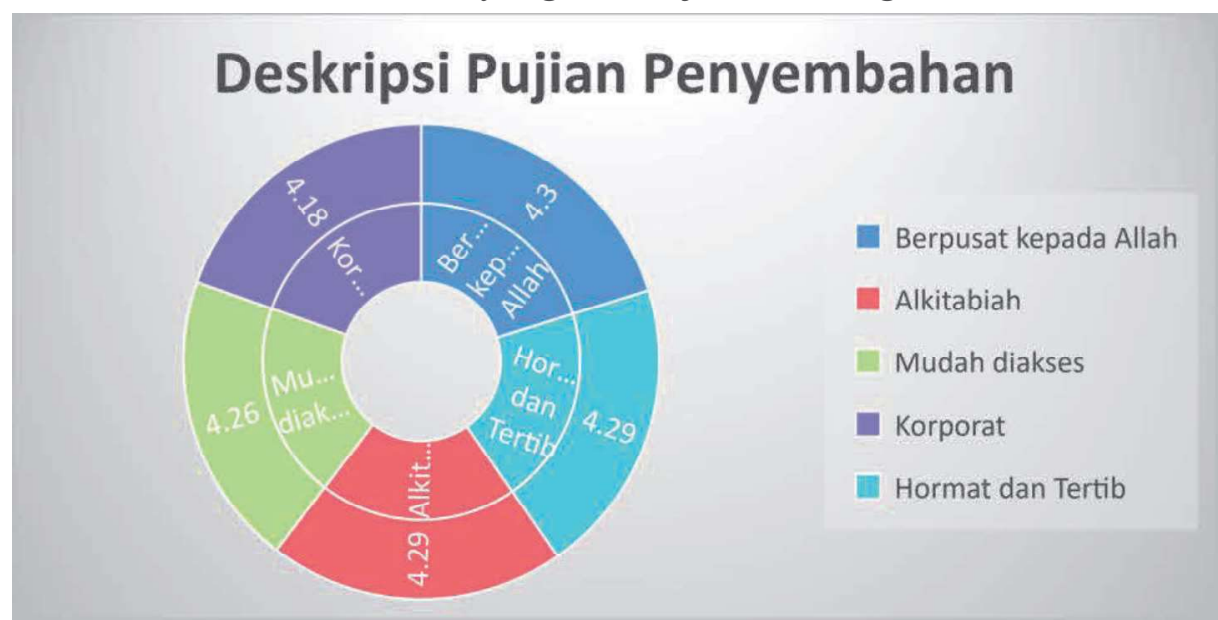

\section{Gambar 1. Deskripsi Pujian Penyembahan}

\section{Musik iringan}

deskripsi Musik iringan dalam ibadah Youth GBI My Home Rawasari yang menjadi daya Tarik bagi remaja dan pemuda. Terbukti dari perolehan rata-rata skor sebesar 4.23 yang menunjukkan kategori baik. Gambaran untuk masing-masing dimensi sebagai berikut

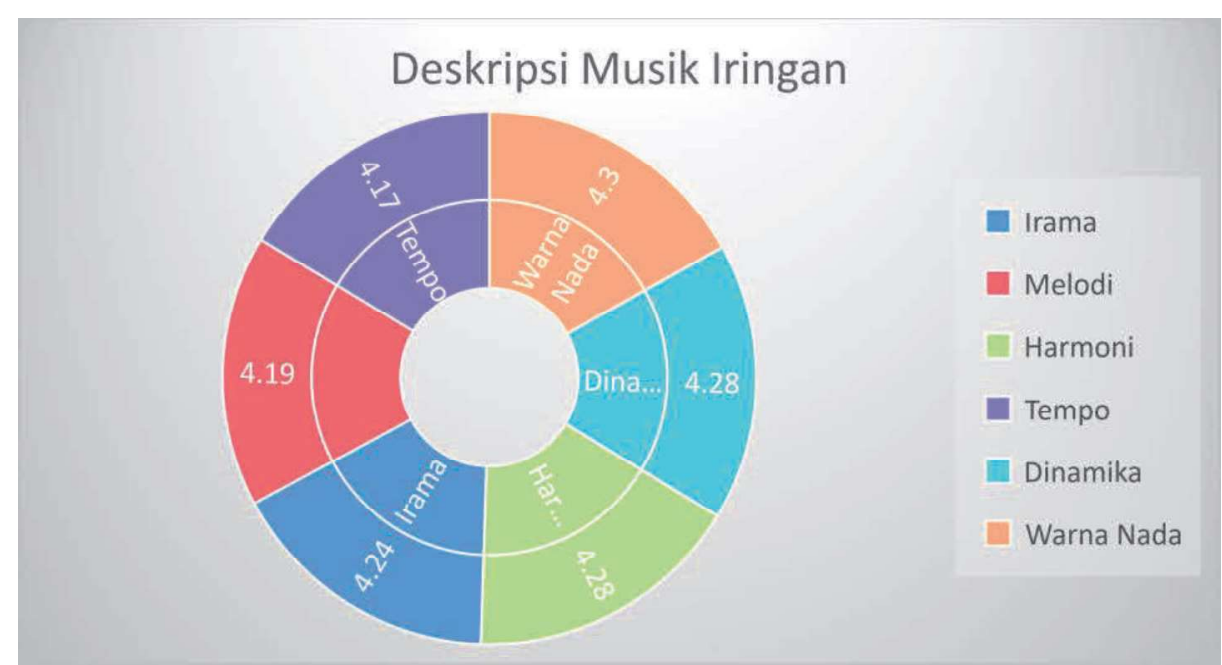

Gambar 2. Deskripsi Musik Iringan 


\section{Remaja dan Minat Kehadiran Ibadah}

Pengertian remaja dan perumusan istilahnya terdapat dalam mengunakannya. Ada yang menggunakan istilah pubertas, ada yang menggunakan istilah adolesensi. Remaja dalam arti adolesensi atau "adolescence" (dalam bahasa inggris), berasal dari bahasa latin "adolence" yang artinya tumbuh ke arah kematangan. Kematangan disini tidak hanya kematangan fisik saja, tetapi terutama kematangan psikologi. $^{8}$

Hasil penelitian menunjukkan bahwa deskripsi minat kehadiran yang diasosiasikan dengan pujian penyembahan dan musik iringan sesuai dengan ciri khas ibadah Youth GBI My Home Rawasari yang menjadi daya Tarik bagi remaja dan pemuda. Terbukti dari perolehan rata-rata skor sebesar 4.24 yang menunjukkan kategori baik. Gambaran untuk masing-masing dimensi sebagai berikut:

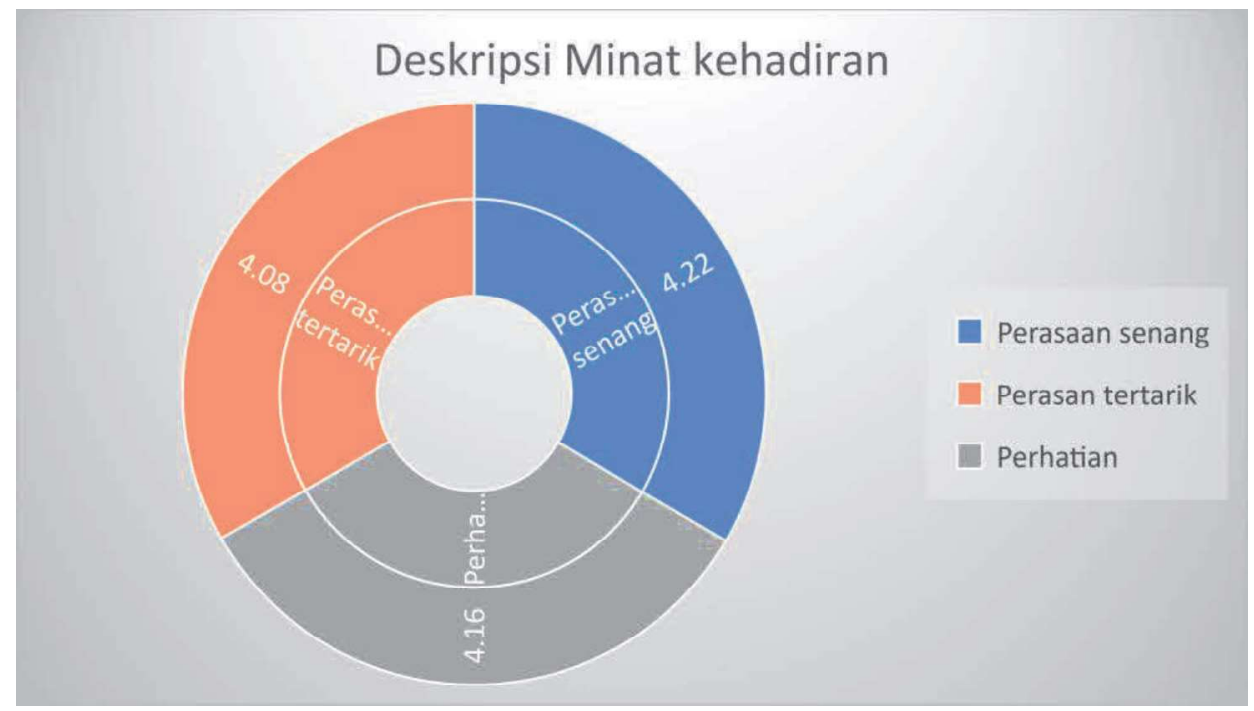

\section{Gambar 3. Deskripsi Minat Kehadiran Remaja}

Gambar di atas menunjukkan bahwa dimensi penelitian dengan skor tertinggi adalah dimensi perasaan senang dalam kelas dengan skor 4.22 dengan kategori baik. Adapula dimensi iklim kelas menjadi dimensi terendah di antara dimensi yang lainnya dengan skor 4.08 meskipun masih berada pada kategori baik. Artinya bahwa minat

${ }^{8}$ Sarlito Wirawan Sarwono, Psikologi Remaja (Jakarta: Rajawali Press, 1989). 
kehadiran akan akan signifikan terfasiltasi oleh pujian penyembahan dan musik iringan. Seperti diketahui bahwa dalam meningkatkan minat kehadiran beribadah remaja maka unsur pujian penyembahan dan music iringan merupakan hal yang tidak dapat dipisahkan. Ketiganya mempunyai hubungan sebab akibat yang tidak dapat dielakkan. Artinya, pujian penyembahan yang menginspirasi juga dipengaruhi musik iringan yang baik.

\section{Pengaruh Pujian Penyembahan \& Musik Iringan Terhadap Minat Kehadiran Ibadah Remaja}

Pujian dan Penyembahan adalah satu dari tema-tema yang paling penting di dalam seluruh Alkitab. Namun ini merupakan salah satu bagian yang paling diabaikan. Gagal dalam melakukan pujian dan penyembahan yang murni sama dengan kehilangan aspek yang vital dari panggilan tertinggi didalam Kristus.

Pujian dan Penyembahan merupakan suatu instrument yang sangat penting dalam ibadah orang percaya., sebab Tuhan pernah berkata bahwa: Aku akan memulihkan pondok Daud yang telah roboh. Dalam kitab perjanjian lama kitab Amos 9:11 "Pada hari itu Aku akan mendirikan kembali pondok Daud yang telah roboh; Aku akan menutup pecahan dindingnya, dan akan mendirikan kembali reruntuhannya; Aku akan membangunnya kembali seperti di zaman dahulu kala," dan pengulangan ayat kembali didalam kitab perjanjian baru kitab kisah para rasul 15:15-16, Tuhan berkata bahwa Ia akan memulihkan pondok Daud yang berarti pemulihan pondok daud adalah sesuatu yang penting dalam PL dan PB.

Pujian harus berfungsi menurut kehendak dan bukan emosi. Setiap orang percaya harus mau dan memutuskan untuk memuji Tuhan sekalipun dalam keadaan tidak senang untuk melakukannya. Pujian tidak tergantung pada perasaan hati, melainkan didasarkan pada kebesaran Tuhan (Mazmur 103). Ciri utama dari pujian adalah adanya perayaan dan sukacita yang meluap-luap. Diekspresikan dengan menyanyi, memekik, memainkan alat musik, manari-nari dan ekspresi luar yang lain. Arah pujian yaitu sesuatu yang kita tujukan langsung kepada Tuhan (bersifat vertikal) pujian pengagungan. Dan sesuatu yang kita ungkapkan kepada orang lain tentang Tuhan (bersifat 
horizontal). Pujian seringkali merupakan persiapan bagi penyembahan, yang maksud pujian sebagai penghantar jemaat sebelum masuk ke dalam penyembahan. Pujian juga dapat dikatakan sebagai pintu gerbang menuju penyembahan.

Hasil penelitian terakhir menunjukkan bahwa pujian penyembahan dan music iringan secara simultan berpengaruh positif terhadap minat kehadiran dengan nilai koefisien sebesar 0,813 , artinya pujian penyembahan dan music iringan berpengaruh kuat terhadap minat kehadiran. Begitu pun dengan hasil perhitungan yang menunjukkan nilai sig. (2-tailed) $=0,000$ lebih kecil dari $=0,005$, yang dapat dimaknai tingkat signifikansi antara keduanya yang menunjukkan hubungan yang signifikan. Adapun koefisien determinasi (r2) yaitu sebesar $0,813=66.1 \%$, artinya pujian penyembahan berpengaruh sebesar $45,4 \%$ terhadap minat kehadiran.

Tabel 1. Pengaruh Pujian Penyembahan Dan Musik Iringan Terhadap Minat Kehadiran Ibadah Remaja

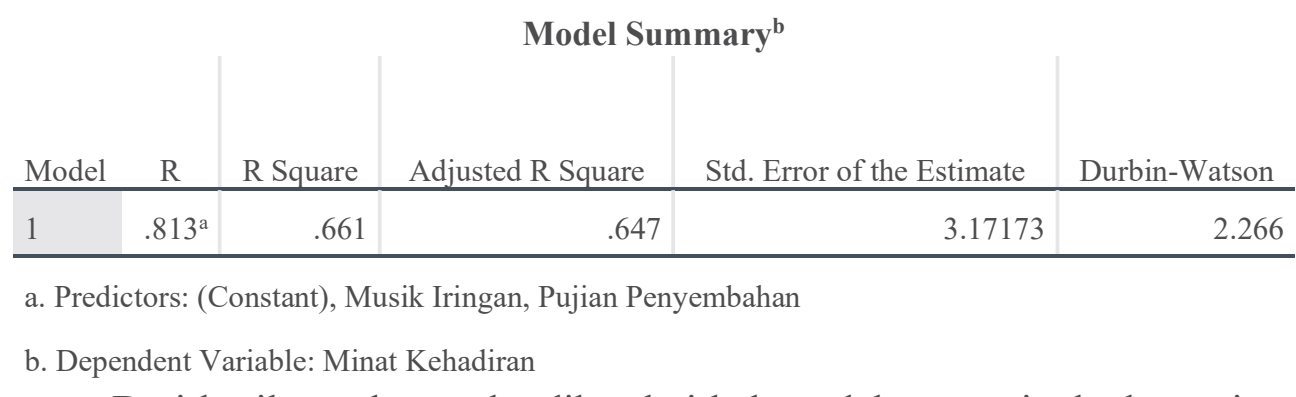

Dari hasil tersebut maka diketahui bahwa dalam meningkatkan minat kehadiran seluruh komponen yang terlibat dalam peribadahan termasuk diantaranya pujian penyembahan dan musik iringan harus benar-benar direncananakan serta dikelola dengan baik, dengan begitu akan memungkinkan mempengaruhi minat seseorang muda untuk beribadah. Hal ini didukung oleh penelitian sebelumnya dimana musik iringan adalah salah satu faktor pertumbuhannya dalam jumlah jemaat. $^{9}$

${ }^{9}$ Lisa Kumala Dewi Suryanto, "Pengaruh Musik Iringan Ibadah Impresif Terhadap Jumlah Jemaat Gki Gejayan Yogyakarta” (Universitas Negeri Yogyakarta, 2014), http://eprints.uny.ac.id/id/eprint/19585.50 


\section{KESIMPULAN}

Menyikapi Pujian penyembahan dan musik iringan memiliki pengaruh yang positif terhadap minat kehadiran ibadah remaja usia 15-18 tahun. Dapat dipahami bahwa Pujian Penyembahan dan musik iringan mempengaruhi minat kehadiran untuk beribadah. Oleh karena itu peneliti dalam hal ini mempunyai pertimbangan dari hasil yang sudah didapatkan maka peneliti menyampaikan:

1. Hendaknya pelaksanaan Pujian Penyembahan di setiap persekutuan terus dilaksanakan dan ditingkatkan sehingga hasilnya akan maksimal dan dipertahankan untuk dapat menjadi gaya hidup setiap remaja yang beribadah di Youth Transformation dan tidak hanya datang waktu PPW Night saja tetapi dalam setiap kegiatan ibadah Youth Transformation.

2. Musik iringan sangat perlu ditingkatkan terutama bagi setiap remaja yang melayani tidak hanya mengandalkan pengurapan tetapi perlu melatih dalam waktu senggang untuk mengupgrade pengetahuan tentang musik iringan yang terdiri dari banyak instrument supaya kehadiran remaja tidak hanya ramai di PPW Night tetapi dalam setiap kegiatan Ibadah Youth Transformation.

3. Melihat besarnya pengaruh Pujian Penyembahan dan musik iringan secara simultan atau bersama - sama yaitu $66,1 \%$ yang berarti penting menjadi salah satu khas dari Youth Transformation yaitu pujian penyembahan dan musik iringan secara bersama-sama supaya terus dipertahankan bahkan ditingkatkan, biar lewat pujian penyembahan dan musik iringan membuat minat kehadiran remaja beribadah bahkan menjadi rol model penjangkauan pada remaja dimasa kini untuk beribadah.

\section{KEPUSTAKAAN}

Ceria, Fredy Simanjuntak, and Evans Dusep Dongoran. "Kajian Teologis Ritual Nyangahatn Dalam Perspektif Penyembahan Menurut Alkitab." Real Didache 5, no. 1 (2020): 89-97.

Mandang, Christina. Serba - Serbi Mengiringi Nyanyian Jemaat. Surabaya: GKI Pondok Tjandra Indah, 1998.

Martasudjita, Emanuel, and Joseph Kristanto. Musik Dan Nyanyian Liturgi : Panduan Untuk Memahami Dan Memilih Dan Nyanyian Liturgi. Yogyakarta: Kanisius, 2007.

Ndoen, Bram Soei. Revolusi Penyembahan Profetik. Yogyakarta: ANDI, 2007.

Rachma, Rasid. Hari Raya Liturgi: Sejarah Dan Pesan Pastoral Gereja. Jakarta: BPK Gunung Mulia, 2005. 
Samuel, Wilfred J. Kristen Kharismatik. Jakarta: BPK Gunung Mulia, 2007.

Sarwono, Sarlito Wirawan. Psikologi Remaja. Jakarta: Rajawali Press, 1989.

Suryanto, Lisa Kumala Dewi. "Pengaruh Musik Iringan Ibadah Impresif Terhadap Jumlah Jemaat Gki Gejayan Yogyakarta.” Universitas Negeri Yogyakarta, 2014. http://eprints.uny.ac.id/id/eprint/19585.

White, James F. Pengantar Ibadah Kristen. Jakarta: BPK Gunung Mulia, 2005. 